УДК 353.1:33.021 (477)

DOI: 10.15587/2313-8416.2018.130475

\title{
РЕГІОНАЛЬНІ АСПЕКТИ СТАЛОГО РОЗВИТКУ В УКРАЇНІ
}

\author{
(С) О. М. Крюкова, С. К. Василик, Г. М. Гузенко, В. М. Клочко, Н. М. Кривошесва
}

Проаналізовано основні принциипи, завдання та процес формування державної регіональної політики Украйни з метою забезпечення сталого розвитку та запропоновано шляхи щзодо підвищення ії ефективності. Досліджено стан бідності в Україні та ї̈ регіонах й запропоновано шляхи щзодо ї̈ зменшення для досягнення першої Цілі сталого розвитку. Розглянуто виникнення нових форм бідності в Україні, пов 'язаних з початком військового конфлікту на території Украӥни

Ключові слова: сталий розвиток, регіональна політика, Цілі сталого розвитку, бідність, межа бідності, прожитковий мінімум

\section{1. Вступ}

В сучасних умовах великого значення набуває концепція сталого розвитку, згідно $з$ якою виробнича та соціальна сфери повинні розвиватися збалансовано, не завдаючи непоправної шкоди довкіллю. Тому сталий розвиток - це розвиток без шкоди для майбутніх поколінь. На міжнародних самітах 3 цього питання визначено основні Цілі сталого розвитку, які включають в себе комплексне вирішення економічних, соціальних та екологічних проблем розвитку людської цивілізації. Ці проблеми повинні вирішуватись на глобальному та національному рівнях, але успіх залежить, значною мірою, від їх вирішення на регіональному рівні, від того, наскільки дієвими та ефективними є регіональна політика сталого розвитку і механізм ії практичної реалізації.

\section{2. Літературний огляд}

Проаналізуємо погляди деяких авторів 3 питань аналізу ефективності державної регіональної політики в Україні.

Ряд авторів [1] вважають, що 3 метою подальшого збалансування соціально-економічного розвитку регіонів України необхідно, щоб стратегії розвитку регіонів відповідали не тільки основним напрямам розвитку держави, але й світовим принципам сталого розвитку.

Серйозним недоліком сучасної практики стратегічного планування на регіональному рівні деякі автори [2] вважають домінування галузевого підходу і недооцінку просторової структури економіки і соціальної сфери. Тому при розробці регіональних стратегій територіальні проблеми, пов'язані з розвитком міст і муніципальних районів, відходять на другий план. Немає рівноправного, систематичного і гармонійного взаємного впливу регіонального та місцевих рівнів у постановці завдань та виборі способів їх вирішення.

Інноваційні сценарії розвитку регіонів орієнтовані на активніше упровадження науковотехнічних досягнень та розвиток інноваційної інфраструктури [3, 4].

Експерти національного інституту стратегічних досліджень [5] зазначають, що регіональна політика в сучасних умовах набуватиме нового сенсу як політика активної участі регіонів у формуванні стра- тегії власного розвитку, тому в якості їх основних пріоритетів стає міжрегіональне співробітництво.

В умовах сталого розвитку регіональна політика ускладнюється, бо в своїй структурі вона має органічно поєднувати три основні блоки: економічну, соціальну та екологічну політики [6]. Але в Україні термін «сталий розвиток» часто вживають лише для означення зростання економічних показників на рівні країни в цілому та окремих іiі регіонів, галузей економіки. Інколи додають також природоохоронні заходи та поліпшення санітарних умов проживання i праці людей [7].

Таким чином, незважаючи на значну кількість праць, присвячених питанням регіонального розвитку, подальшої уваги науковців потребують надзвичайно актуальні для сучасної української держави проблеми формування та реалізації регіональної політики в умовах сталого розвитку.

\section{3. Мета та задачі дослідження}

Метою статті є аналіз основних принципів та завдань регіональної політики щодо забезпечення сталого розвитку, а також дослідження бідності і шляхів їі подолання в Україні та регіонах для досягнення першої Цілі сталого розвитку. задачі:

Для досягнення мети були поставлені наступні

1. Проаналізувати процес формування державної регіональної політики сталого розвитку в Україні та визначити напрями підвищення їі ефективності. регіонах.

2. Дослідити проблему бідності в Україні та іiі Україні.

3. Запропонувати шляхи подолання бідності в

4. Регіональна політика сталого розвитку в Україні та її першочергова Ціль - подолання бідності

Визначення нових підходів до формування цілей, пріоритетів та механізмів реалізації регіональної політики та його розвитку зумовлюється європейським вибором України.

Сучасна регіональна політика ЄС має три основні напрями. По-перше, робиться наголос на сприянні економічному наближенню, щоб допомогти менш розвиненим регіонам (розташованим переважно в нових країнах-учасниках) у зменшенні 
відставання від більш розвинених регіонів. Подруге, впроваджується система заходів, спрямованих на покращення регіональної конкурентоспроможності й занятості. Третя категорія стратегій спрямована на сприяння співпраці між регіонами і країнами для зменшення економічного значення національних кордонів [8].

Нові підходи в регіональній політиці європейських держав усе більше спрямовуються на передачу повноважень і ресурсів на субнаціональний рівень, завдяки чому регіони можуть самі розвивати власні території й підвищувати свою конкурентоспроможність. Міністерства й інші центральні органи влади діють переважно як координатори та партнери регіонального розвитку, що його здійснюють самі регіони.

На нашу думку, пріоритет сталого регіонального розвитку в сучасних умовах може мати в Україні такі сутнісні характеристики:

- інноваційний характер - які принципово нові технології розробки будуть упроваджені у результаті реалізації пріоритету; наскільки використовуватимуться нові організаційні механізми стимулювання регіонального розвитку (зокрема, кластери);

- ресурсна ефективність (у першу чергу - енергоефективність) - наскільки реалізація пріоритету дозволить зменшити споживання певного виду ресурсу;

- вирішення проблем розселення і працевлаштування - скільки може бути створено робочих місць і яким буде коефіцієнт їх навантаження;

- екологічна дружність - наскільки реалізований пріоритет буде погіршувати екологічну ситуацію i як / чи можна цього уникнути;

- покращення стану розвитку інфраструктури - скільки транспортних комунікацій буде побудовано / удосконалено в результаті реалізації пріоритету;

- соціальний ефект - наскільки покращиться рівень життя населення;

- сутність пріоритету - пріоритет є простим віддзеркаленням загальнонаціонального пріоритету чи його подальшим розвитком і удосконаленням;

- масштаб охоплення пріоритету - пріоритет $€$ наскрізним для ієрархії рівнів управління («держава регіон - територія») чи локальним (для певного регіону або для групи регіонів, для окремої території);

- термін дії реалізованого пріоритету і наслідки - довгостроковий ефект, середньострокова інерційність, короткотермінове задоволення внутрішніх потреб регіону.

В 2015 р. на саміті ООН зі сталого розвитку (Нью-Йорк) в підсумковому документі «Перетворення нашого світу: порядок денний у сфері сталого розвитку до 2030 року» було затверджено нові орієнтири розвитку - 17 Цілей та 169 завдань.

Базуючись на цьому документі, в 2017 р. Уряд України представив Національну доповідь «Цілі сталого розвитку: Україна», яка визначила базові показники для досягнення Цілей сталого розвитку (ЦСР) та розробила національну систему ЦСР - 86 завдань розвитку та 172 показники для моніторингу їх виконання [9]. Тому при розробці регіональних політик обов'язково потрібно, щоб вони були прив'язані до ЦСР.

\section{5. Результати дослідження}

До 2030 р. в Україні чітко визначено 4 основних напрямки завдань ЦСР:

- справедливий соціальний розвиток;

- стале економічне зростання та зайнятість;

- ефективне управління;

- екологічна рівновага та розбудова стійкості [9].

Слід зазначити, що першою ЦСР людства $є$ «подолання бідності у всіх іiі формах та усюди», для чого планується ліквідувати крайню бідність (проживання на суму менш ніж 1,25 дол. США на день) для всіх людей всього світу.

За стандартами ООН, якщо людина витрачає на проживання та продукти харчування суму меншу, ніж 5 дол. США на день, а на місяць - меншу, ніж 150 дол. США, то вона живе за порогом (межею) бідності. Якщо ж ці суми складають, відповідно, 1,25 та 37,5 дол. США, то наступає поріг злиднів. В Україні в 2017 р. за даними ООН за межею бідності проживали від 60\% (березень) до 80\% (серпень) населення $[10,11]$.

Монетарну бідність, як соціальну категорію, можна проаналізувати за допомогою категорій абсолютної та відносної бідності.

Абсолютна бідність свідчить про те, що на свій дохід індивід не може придбати товари та послуги, необхідні для задоволення його основних соціальних потреб, специфічних для даного суспільства. Кількісним критерієм іï вимірювання виступає поріг (межа) бідності або прожитковий мінімум. Закон «Про державний бюджет України на 2018 рік» встановлює прожитковий мінімум впродовж року від 1700 грн. (з 01.01.18) до 1853 грн. (з 01.12.18), тобто приблизно від 60 до 70 дол. США на місяць [12], при цьому він не враховує медичні послуги, освіту тощо. Таким чином, в соціальних стандартах України поки що, на жаль, закладено поріг абсолютної бідності.

Для виправлення цієї ситуації необхідно на державному рівні затвердити поняття «межа (поріг) бідності», пов'язавши його значення зі стандартами ООН та Світового банку, і при прийнятті Державного бюджету основні показники узгоджувати з ним. Також структура прожиткового мінімуму має бути приведена у відповідність до міжнародних стандартів.

Починаючи 32014 р., коли відбулися окупація Криму та військовий конфлікт на сході України, в усіх регіонах спостерігалась тенденція збільшення масштабів абсолютної бідності. Крім того, в цей час 3'явились нові форми бідності [9]:

1) раптова бідність - втрата житла, майна та джерел для існування внаслідок збройних конфліктів на сході України;

2) медична бідність - через захворювання, неспроможність отримати лікування або неможливість придбати ліки;

3) бідність за ознакою заборгованості - заборгованість перед банківськими установами, яка виникла за надвисокі ставки по кредитуванню на фоні зниження реальних доходів населення.

Показник відносної бідності характеризує ситуацію, коли індивід не має достатньо коштів, щоб вести прийнятний для даного суспільства стиль життя. Протягом 2000-2013 рр. в Україні відносна бід- 
ність мала тенденцію до скорочення у великих містах з $25 \%$ до 15,9\%, а в малих містах та у сільській місцевості була досить високою і майже не знижувалась 26,9 \% та 34,1 \% відповідно [13].

Проаналізуємо показник середньомісячної заробітної плати в районах України за січень 2018 р. (розраховано на основі даних [14]):

1. Центральний район (Київська та Черкаська області і м. Київ) - 8744 грн.

2. Донецький район (Донецька і Луганська області) - 7398 грн.

3. Придніпровський район (Дніпропетровська, Запорізька, Кіровоградська області) - 7180 грн.

4. Причорноморський район (Миколаївська, Одеська, Херсонська області) - 6786 грн.

5. Східний район (Харківська, Полтавська, Сумська області) - 6739 грн.

6. Карпатський район (Львівська, Закарпатська, Івано-Франківська та Чернівецька області) - 6582 грн.

7. Поліський район (Рівненська, Волинська, Житомирська і Чернігівська області) - 6321 грн.

8. Подільський район (Вінницька, Тернопільська та Хмельницька області) - 6297 грн.

В цілому по Україні за цей період середньомісячна номінальна зарплата складала - 7711 грн. [15].

В умовах, коли рівень заробітних плат є невисоким, доцільно узгодити поріг оподаткування з розміром прожиткового мінімуму.

Проблеми з бідністю, нестабільна економічна та політична ситуація, військовий конфлікт на сході
України призвели до того, що зменшилась чисельність населення 348230 тис. чол. в 2002 р. до 42365 тис. чол. станом на 01.02.2018 р. Найбільший відтік міграційного руху був з Донецької, Луганської, Вінницької, Херсонської та Запорізької областей [15]. Історія свідчить, що усі ці проблеми та форми бідності не можна подолати лише за допомогою традиційних методів 3 боку держави (з 2001 р. в Україні діє державна програма «Стратегія подолання бідності»). Для подолання бідності в Україні та іiі регіонах а слід перейти від політики вирішення точкових проблем окремих регіонів до комплексного підходу.

\section{6. Висновки}

1. В результаті аналізу процесу формування державної регіональної політики України визначені іiі недоліки (зокрема, обмеженість галузевого підходу). Встановлено характеристики сталого регіонального розвитку в Україні і зроблено висновок про необхідність узгодження державної регіональної політики України з Цілями сталого розвитку.

2. В результаті дослідження проблеми бідності в Україні виявлено, що в соціальних стандартах закладено поріг абсолютної бідності, оскільки структура прожиткового мінімуму не відповідає міжнародним стандартам.

3. Узгодити встановлення соціальних нормативів (зокрема, порогу оподаткування) 3 розміром прожиткового мінімуму.

\section{Література}

1. Ісаченко Д. А. Практика стратегічного планування розвитку регіонів // Регіональна економіка. 2009. № 4. С. $24-32$.

2. Швецов А. Систематизация инструментов перспективного планирования территориального развития: настоятельная необходимость и конкретные предложения // Вопросы экономики. 2009. № 5. С. 12-47.

3. Шевченко О. В. Стратегічне планування регіонального розвитку: відповідність критеріям інноваційності // Вісник Донецького національного університету. Серія В: Економіка і право. 2009. № 5. С. 362-366.

4. Шевченко О., Жук В., Кушнір М. Щодо першочергових заходів підвищення ефективності стратегічного планування розвитку регіонів України. Аналітична записка // Національний інститут стратегічних досліджень. 2011. URL: http://www.niss.gov.ua/articles/382

5. Шевченко О. В. Соціально-економічний розвиток регіонів України: тенденції першої половини 2017 року // Національний інститут стратегічних досліджень. 2017. URL: http://www.niss.gov.ua/content/articles/files/region_Ukr-d43fd.pdf

6. Герасимчук 3. В. Регіональна політика сталого розвитку: теорія, методологія, практика: монографія. Луцьк: Надстир'я, 2008. 528 с.

7. Стельмащук А. М., Стельмащук Ю. А. Сталий розвиток національної економіки на основі оптимальної взаємодії суспільства і природи // Сталий розвиток економіки. 2017. № 4 (37). С. 5-13.

8. European regional policy, an inspiration for countries outside the EU? Applying the principles, sharing the lessons, exchanging experience. URL: http://ec.europa.eu/regional_policy/sources/docgener/presenta/international/external_en.pdf

9. Цілі Сталого Розвитку: Україна. Національна доповідь. URL: http://menr.gov.ua/files/docs/Національна\% 20доповідь\%20ЦСР\%20України_липень\%202017\%20ukr.pdf

10. Рівень бідності в Україні у 2017 році знизився на 5 \% - КMIC. URL: http://gordonua.com/ukr/news/money/rivenbidnosti-v-ukrajini-u-2017-rotsi-zmenshivsja-na-5-kmis-225925.html

11. 80 відсотків населення України живе за межею бідності - OOH. URL: http://www.ukrpress.info/2017/08/28/80відсотків-населення-україни-живе-за-м/

12. Держбюджет - 2018: мінімальна зарплата й прожитковий мінімум. URL: http://www.interbuh.com.ua/ ua/documents/onenews/114374

13. Струченков О. Динаміка бідності в Україні. URL: https://commons.com.ua/uk/dynamika-bidnosti-in-ua/

14. Середньомісячна зарплата по регіонам України в 2018 p. URL: http://index.minfin.com.ua/labour/salary/average

15. Державна служба статистики України. URL: http://www.ukrstat.gov.ua 
Крюкова Ольга Миколаївна, кандидат економічних наук, доцент, завідувач циклової комісії економіки та маркетингу, Харківський торговельно-економічний коледж Київського національного торговельноекономічного університету, вул. Клочківська, 202, м. Харків, Україна, 61045

E-mail: economyc.htek.103@gmail.com

Василик Сергій Костянтинович, кандидат економічних наук, доцент, викладач, Циклова комісія економіки та маркетингу, Харківський торговельно-економічний коледж Київського національного торговельно-економічного університету, вул. Клочківська, 202, м. Харків, Україна, 61045

E-mail: vasylyks@gmail.com

Гузенко Ганна Миколаївна, кандидат економічних наук, доцент, викладач, методист, Циклова комісія економіки та маркетингу, Харківський торговельно-економічний коледж Київського національного торговельно-економічного університету, вул. Клочківська, 202, м. Харків, Україна, 61045

E-mail: GuzenkoCanna@gmail.com

Клочко Віталій Миколайович, кандидат економічних наук, доцент, викладач, Циклова комісія економіки та маркетингу, Харківський торговельно-економічний коледж Київського національного торговельно-економічного університету, вул. Клочківська, 202, м. Харків, Україна, 61045

E-mail: vitaliyklochko26@gmail.com

Кривошесва Надія Михайлівна, Викладач вищої категорії, Циклова комісія економіки та маркетингу. Харківський торговельно-економічний коледж Київського національного торговельно-економічного університету, вул. Клочківська, 202, м. Харків, Україна, 61045

E-mail: predkisila@gmail.com

УДК 332.1(477.54)

DOI: $10.15587 / 2313-8416.2018 .131607$

\section{ІМІДЖ-МЕНЕДЖМЕНТ ЯК АКТИВНИЙ ІНСТРУМЕНТ СОЦАЛЬНО- ЕКОНОМІЧНОГО РОЗВИТКУ РЕГІОНУ (НА ПРИКЛАДІ РОЗВИТКУ СІЛЬСЬКОГО ЗЕЛЕНОГО ТУРИЗМУ У ХАРКІВСЬКІЙ ОБЛАСТІ)}

\section{(C) Д. Г. Дармостук}

Проаналізовано основні принциии, завдання та прочес формування іміджу території як окремого регіону, так і країни в цілому. Розглянуто три групи факторів, які впливають на формування іміджу території. Досліджено імідж окремо взятого регіону на прикладі Харківської області і запропоновано практичні можливості застосування імідж-менеджменту щодо сочіально-економічного розвитку регіону в иілому та сільських територій через розвиток сільського зеленого туризму. Запропоновано модель впливу імідж-менеджменту як активного інструменту соиіально-економічного розвитку регіону

Ключові слова: імідж території, імідж-менеджмент, туризм, сільський зелений туризм, об'єкт $i$ суб'єкт управління

\section{1. Вступ}

У сучасному глобальному світі імідж території як окремого регіону, так і країни в цілому мають неабияке значення для їх соціально-економічного розвитку. Імідж конкретної території - це сукупність переконань, уявлень і вражень, закріплених у масовій свідомості. Це - певний образ, часто доволі стереотипний. Наприклад, місто Женева у пересічного громадянина викликає декілька асоціацій: виробництво шоколаду, розвинений банківський сектор, брендові годинники та ювелірні вироби, місце перебування штаб-квартири низки міжнародних організацій.

\section{2. Літературний огляд}

Проаналізуємо погляди деяких авторів 3 питань ефективності іміджу-менеджменту як активного інструменту соціально-економічного розвитку регіону.
Ряд авторів вважають [1], що на формування іміджу території найчастіше впливають три групи факторів. До першої групи належать: природноресурсний потенціал, національно-культурний спадок, географічне положення, загальна площа, вихід до моря, історичні події, які вплинули на розвиток території, форма державного устрою (для країни). Це - відносно сталі фактори. Друга група - відносно динамічні фактори: соціально-психологічні настрої у суспільстві, морально-етичні аспекти його розвитку; структура, характер та особливості діяльності суспільно-політичних об'єднань. Остання група - відносно динамічні, інституційні фактори: показники економічної стійкості, правового простору, механізмів державного регулювання.

Деякі автори $[2,3]$ доводять, що тенденції розвитку окремої території (країни) в певний час можуть 